Reprod. Nutr. Dévelop., 1987, 27 (3), 689-700.

\title{
Effects of age and live weight on the sexual development of gilts and boars fed two planes of nutrition
}

\author{
Armelle PRUNIER, M. BONNEAU, M. ETIENNE
}

Station de Recherches Porcines, I.N.R.A. Saint-Gilles, 35590 l'Hermitage, France

Summary. The aim of the present study was to determine the respective influences of age and live weight on the sexual development of boars and gilts. The Large White animals used were fed on a liberal plane of nutrition close to ad libitum (CTRL group) or restricted on a live weight basis (SA and SW groups). CTRL and SW pigs were slaughtered and their genital tracts examined at $125 \mathrm{~kg}$ of live weight; those in the SA group were slaughtered and examined at the same age as their CTRL littermates. Control and SA boars and gilts were about 180 and 200 days old, respectively, while SW boars and gilts were about 240 and 260 days old, respectively. The SA group pigs weighed about $90 \mathrm{~kg}$.

Testis weight was influenced by live weight but not by age, while epididymis and seminal vesicle weights and bulbourethral gland weight and length were dependent on both age and live weight.

Age had a significant influence on puberty attainment in gilts while live weight had nearly no effect. Percentages of cyclic gilts in the CTRL, SW and SA groups were 32, 79 and 20 , respectively. Ovarian weight was mainly dependent on live weight in cyclic as well as in prepuberal gilts. In the latter animals, the weight and length of uterine horns and cervix were influenced by both age and live weight, whereas in cyclic gilts the only obvious effect was that of age on uterine horn weight. Season of birth (autumn vs spring) had no effect on the puberty attainment of gilts.

\section{Introduction.}

In a recent review, Kirkwood and Aherne (1985) wondered whether age and live weight are reliable indicators of physiological development. There is some controversy about their respective influences on gilt sexual maturity. While some authors found that age at first oestrus was a more constant factor than weight (Robertson et al., 1951 ; Lodge and MacPherson, 1961 ; Pay and Davies, 1973 ; Hughes and Cole, 1975 ; Friend, 1977 ; Den Hartog, 1985), others indicated that retarded growth due to food restriction delayed the onset of puberty (Lodge and MacPherson, 1963 ; Friend, 1973 ; Mavrogenis and Robison, 1976 ; Friend et al., 1981 ; Etienne et al., 1983). Dutt and Barnhart (1959) and Einarsson et al. (1979) found that age effect prevailed over that of live weight in boar sexual development, while Niwa (1954), Kim et al. (1976) and Uzu (1979) claimed that live weight at pubertv was a more constant factor than age. 
The aim of the present experiment was to determine the respective influences of age and live weight on the sexual development of boars and gilts. The genital tracts of these animals fed two planes of nutrition were examined around the expected time of puberty either at a given weight and different ages or at a given age and different weights. Fat androstenone levels were also measured in boars and published by Bonneau (1987).

\section{Material and methods.}

Animals. - A total of 280 Large-White pigs, 140 boars and 140 gilts from 60 litters, were allocated to three treatment groups on a within-litter and sex basis. All the animals received the same diet containing $12.93 \mathrm{MJ}$ of digestible energy per $\mathrm{kg}, 17.3 \%$ of protein and $0.83 \%$ of lysine. Up to slaughter, the control pigs (CTRL) were fed according to a liberal scale, close to ad libitum and ranging between $1.2 \mathrm{~kg} /$ day at 20 to $25 \mathrm{~kg}$ of live weight and $3.2 \mathrm{~kg} /$ day from $105 \mathrm{~kg}$ of live weight. Restricted pigs (SA and SW) were offered $70 \%$ of the CTRL diet on a live weight basis. All the animals were weighed at weekly intervals and on the day of slaughter.

Groups of 5 boars or gilts were housed in separate adjacent pens under natural daylight. The animals of two contiguous pens had limited physical contact through the gates.

The pigs of the CTRL and SW groups were slaughtered at about $125 \mathrm{~kg}$ of live weight and those of the SA group at the same age as their CTRL littermates (table 1). The genital tracts were removed and trimmed of their ligaments. The length of the bulbourethral glands in boars and of the cervix and uterine horns in gilts was measured. The respective weights of the testes, epididymis, seminal vesicles and bulbourethral glands were determined in boars and those of the ovaries, corpora lutea (when present), uterine horns and cervix in gilts. The vagina

TABLE 1

Age and live weight of animals at slaughter (means \pm SEM).

\begin{tabular}{lcccc}
\hline & Treatment & CTRL & SW & SA \\
\hline \multirow{3}{*}{ Males } & Age (d) & $183.7 \pm 1.6^{\mathrm{b}}$ & $241.5 \pm 2.6^{\mathrm{a}}$ & $183.2 \pm 1.7^{\mathrm{b}}$ \\
\cline { 2 - 5 } & Live weight $(\mathrm{kg})$ & $126.2 \pm 0.4^{\mathrm{a}}$ & $125.0 \pm 0.2^{\mathrm{a}}$ & $90.7 \pm 1.6^{\mathrm{b}}$ \\
\cline { 2 - 5 } & $\mathrm{n}$ & 46 & 51 & 47 \\
\hline \multirow{3}{*}{ Females } & Age $(\mathrm{d})$ & $197.3 \pm 1.9^{\mathrm{b}}$ & $261.4 \pm 3.5^{\mathrm{a}}$ & $197.4 \pm 2.1^{\mathrm{b}}$ \\
\cline { 2 - 5 } & Live weight $(\mathrm{kg})$ & $125.5 \pm 0.3^{\mathrm{a}}$ & $125.2 \pm 0.3^{\mathrm{a}}$ & $91.9 \pm 1.6^{\mathrm{b}}$ \\
\hline & $\mathrm{n}$ & 47 & 48 & 41 \\
\hline
\end{tabular}

In the same line, means with different superscripts differ significantly $(P<0.05)$. 
was not dissociated from the cervix, so that cervix weight and length included that of the vagina. The number of corpora lutea and the number and size of antral follicles were recorded. Ovarian stage of maturity was determined according to the classification of Etienne and Legault (1974):

- class 1 : immature ovaries with no follicle $>2 \mathrm{~mm}$ in diameter ;

- class 2 : immature ovaries with less than 5 follicles $>5 \mathrm{~mm}$ in diameter on both ovaries :

- class 3 : immature ovaries with 5 or more follicles $>5 \mathrm{~mm}$ in diameter on both ovaries ;

- class 4 : ovaries at the first cycle with preovulatory follicles $(6$ to $8 \mathrm{~mm}$ in diameter) or corpora lutea ;

- class 5 : cyclic ovaries with corpora albicans.

The right side of the carcass was used to estimate body composition at slaughter. Percentages of total muscle and fat were estimated by multiple regression equations on the weights of the different joints (Desmoulin et al., 1976).

Four replicates of the experimental design were carried out during spring 1982 ( 30 boars and 45 gilts born between April 10 and May 21), autumn 1982 (45 boars and 30 gilts born between October 29 and November 13), spring 1983 (45 boars and 30 gilts born between March 31 and May 4) and autumn 1983 (30 boars and 45 gilts born between September 32 and October 12).

Statistical analysis. - The effects of the treatments on the percentage of gilts in each stage of sexual maturity were assessed with the $\chi^{2}$ test. The other data were analyzed using analysis of variance. The model for growth performance and carcass traits included replicate, sex and treatment for the whole population, and ovarian stage of maturity and treatment for the gilts. The model for genital tract development included replicate and treatment in each sex, and ovarian stage of maturity and treatment for the gilts.

Partial correlations between genital tract developmental traits and age, or live weight, were calculated in each sex after the common effect of live weight, or age, was eliminated by linear regression.

\section{Results.}

\section{Feed consumption and growth performance.}

The overall levels of feed restriction achieved ranged between 24 and $29 \%$ and resulted in a 31 to $36 \%$ reduction of the average daily gain (table 2). Whatever the treatment group, the daily gain was higher in boars than in gilts and the difference was accentuated with increasing live weight.

At slaughter, restricted animals were leaner than ad libitum ones. The difference was greater between CTRL and SA animals than between the CTRL and SW groups. In each treatment group, the gilts were fatter than the boars. The difference between the sexes was less at around $90 \mathrm{~kg}$ of live weight (SA group) than around $125 \mathrm{~kg}$ (CTRL and SW groups). 
TABLE 2

Feed consumption, growth performance and carcass characteristics (means \pm SEM).

\begin{tabular}{cccccc}
\hline \multicolumn{2}{c}{ Treatment } & & \multicolumn{2}{c}{ Level of significance } \\
\hline CTRL & SW & SA & Sex & Treatment \\
\hline
\end{tabular}

\begin{tabular}{|c|c|c|c|c|c|}
\hline $\begin{array}{l}26-60 \mathrm{~kg} \\
\begin{array}{l}\text { Feed consumption } \ldots \ldots \ldots \\
(\mathrm{kg} / \text { day }) \ldots \ldots \ldots \ldots \ldots\end{array}\end{array}$ & $\begin{array}{l}\text { Boars } \\
\text { Gilts }\end{array}$ & $\begin{array}{l}1.87 \\
1.87\end{array}$ & $\begin{array}{l}1.37 \\
1.38\end{array}$ & $\begin{array}{l}1.36 \\
1.37\end{array}$ & Not determinated \\
\hline $\begin{array}{l}\text { Daily gain } \\
\text { (g/day) .. }\end{array}$ & $\begin{array}{l}\text { Boars } \\
\text { Gilts }\end{array}$ & $\begin{array}{l}694 \pm 12^{a} \\
659 \pm 13^{a}\end{array}$ & $\begin{array}{l}476 \pm 9 b \\
455 \pm 11^{b}\end{array}$ & $\begin{array}{r}475 \pm 12^{\mathrm{b}} \\
453 \pm 11^{\mathrm{b}}\end{array}$ & $P<0.05 P<$ \\
\hline
\end{tabular}

\begin{tabular}{|c|c|c|c|c|c|}
\hline $\begin{array}{l}60-90 \text { kg } \\
\text { Feed consumption } \ldots \ldots \ldots \\
\text { (kg/day) } \ldots \ldots \ldots \ldots \ldots\end{array}$ & $\begin{array}{l}\text { Boars } \\
\text { Gilts }\end{array}$ & $\begin{array}{l}2.69 \\
2.69\end{array}$ & $\begin{array}{l}2.00 \\
1.99\end{array}$ & $\begin{array}{l}1.95 \\
1.96\end{array}$ & Not determinated \\
\hline $\begin{array}{l}\text { Daily gain } . \\
\text { (g/day) ... }\end{array}$ & $\begin{array}{l}\text { Boars } \\
\text { Gilts }\end{array}$ & $\begin{array}{l}941 \pm 17^{a} \\
884 \pm 17^{a}\end{array}$ & $\begin{array}{l}626 \pm 13^{b} \\
569 \pm 14^{c}\end{array}$ & $\begin{array}{l}635 \pm 14^{b} \\
563 \pm 15^{c}\end{array}$ & $P<0.01 P<0.01$ \\
\hline
\end{tabular}

\begin{tabular}{|c|c|c|c|c|c|}
\hline $\begin{array}{l}90 \mathrm{~kg} \text {-slaughter } \\
\text { Feed consumption } \\
(\mathrm{kg} / \text { day }) \ldots \ldots \ldots\end{array}$ & $\begin{array}{l}\text { Boars } \\
\text { Gilts }\end{array}$ & $\begin{array}{l}3.06 \\
3.05\end{array}$ & $\begin{array}{l}2.16 \\
2.16\end{array}$ & $\begin{array}{l}- \\
-\end{array}$ & Not determinated \\
\hline $\begin{array}{l}\text { Daily gain } \\
\text { (g/day) } .\end{array}$ & $\begin{array}{l}\text { Boars } \\
\text { Gilts }\end{array}$ & $\begin{array}{l}961 \pm 23^{a} \\
831 \pm 14^{b}\end{array}$ & $\begin{array}{l}616 \pm 17^{c} \\
513 \pm 12^{d}\end{array}$ & - & $P<0.01 P<0.01$ \\
\hline
\end{tabular}

\begin{tabular}{|c|c|c|c|c|c|}
\hline $\begin{array}{l}\text { Slaughter } \\
\% \text { lean tissue ..... }\end{array}$ & $\begin{array}{l}\text { Boars } \\
\text { Gilts }\end{array}$ & $\begin{array}{l}49.1 \pm 0.4^{\mathrm{c}} \\
46.0 \pm 0.5^{\mathrm{d}}\end{array}$ & $\begin{array}{l}54.9 \pm 0.3^{a b} \\
50.7 \pm 0.3^{c}\end{array}$ & $\begin{array}{l}56.5 \pm 0.4^{a} \\
54.4 \pm 0.4^{b}\end{array}$ & $P<0.01 P<0.01$ \\
\hline \multirow[t]{2}{*}{$\%$ fat tissue } & Boars & $27.1 \pm 0.5^{c}$ & $19.3 \pm 0.4^{\mathrm{ab}}$ & $18.3 \pm 0.3^{a}$ & \multirow[t]{2}{*}{$P<0.01$} \\
\hline & Gilts & $32.6+0.6^{d}$ & $25.7 \pm 0.5^{c}$ & $20.6+0.4^{b}$ & \\
\hline
\end{tabular}
possible.

Feed consumption : animals were fed collectively. Therefore analysis of individual data was not

Means with different superscripts differ significantly $(P<0.05)$.

2. Boar genital tract development.

Testis weight was not different in CTRL and SW boars, whereas it was significantly lower in SA animals (table 3). Relative to body weight, testis weight was similar in the three groups (CTRL : $4.5 \%$; SW : $4.6 \%$; SA : $4.7 \%$ ). The

TABLE 3

Genital tract development in boars at s/aughter (means \pm SEM).

\begin{tabular}{ccr}
\hline & Treatment \\
\hline CTRL & SW & \multicolumn{1}{c}{ SA } \\
\hline $571 \pm 19^{\mathrm{a}}$ & $577 \pm 14^{\mathrm{a}}$ & $427 \pm 17^{\mathrm{b}}$ \\
$119 \pm 3^{\mathrm{b}}$ & $146 \pm 3^{\mathrm{a}}$ & $91 \pm 3^{\mathrm{c}}$ \\
$286 \pm 18^{\mathrm{b}}$ & $356 \pm 19^{\mathrm{a}}$ & $182 \pm 14^{\mathrm{c}}$ \\
$227 \pm 12^{\mathrm{b}}$ & $273 \pm 11^{\mathrm{a}}$ & $167 \pm 11^{\mathrm{c}}$ \\
$14.4 \pm 0.3^{\mathrm{b}}$ & $15.4 \pm 0.3^{\mathrm{a}}$ & $12.7 \pm 0.3^{\mathrm{c}}$
\end{tabular}

In the same line, means with different superscripts differ significantly $(P<0.05)$. 
weights of the epididymis and accessory sex glands in the three groups were significantly different as follows : SW $>$ CTRL $>$ SA.

Partial correlation of testis weight with live weight was high, while correlation with age was close to zero (table 4). The partial correlations with age and live weight were similar and significant for the other traits.

TABLE 4

Coefficients of partial correlation between genital tract development traits and age or live weight in boars.

\begin{tabular}{|c|c|c|}
\hline & \multicolumn{2}{|c|}{ Partial correlation with } \\
\hline & Age & Live weight \\
\hline $\begin{array}{l}\text { Testis weight }(g) \ldots \ldots \ldots \ldots \ldots \ldots \ldots \\
\text { Epididymis weight }(g) \ldots \ldots \ldots \ldots \ldots \ldots \\
\text { Seminal vesicle weight }(g) \ldots \ldots \ldots \ldots \ldots \\
\text { Bulbourethral gland weight }(g) \ldots \ldots \ldots \ldots \\
\text { Bulbourethral gland length }(\mathrm{cm}) \ldots \ldots \ldots \ldots\end{array}$ & $\begin{array}{l}0.01 N S \\
0.49^{* *} \\
0.37^{* *} \\
0.35^{* *} \\
0.30^{*}\end{array}$ & $\begin{array}{l}0.58^{* *} \\
0.54^{* *} \\
0.37^{* *} \\
0.33^{* *} \\
0.36^{* *}\end{array}$ \\
\hline
\end{tabular}

NS $P>0.1$

* $P<0.05$

** $P<0.01$

3. Gilt sexual development.

Attainment of puberty. - Sixty-one gilts (45\%) were pubertal at slaughter. One was slaughtered during the follicular phase of the first oestrous cycle.

The treatment had a significant effect $(P<0.01)$ on gilt distribution among the 5 classes of ovarian maturity (fig. 1). Gilts in the SW group were more

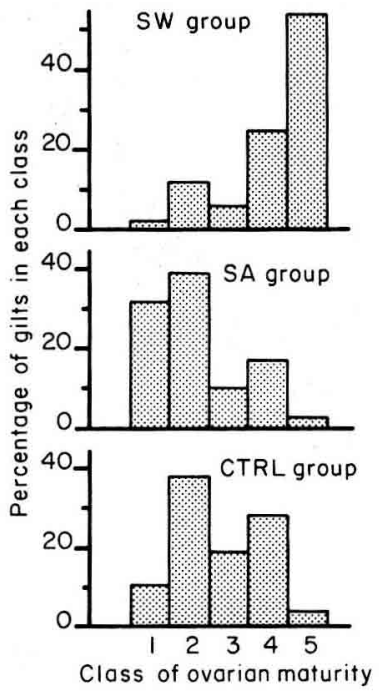

FIG. 1. - Effects of treatment on ovarian maturity in gilts.

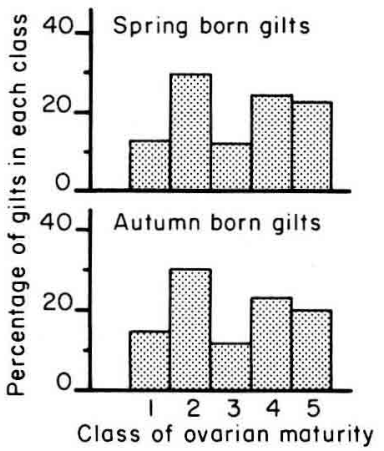

FIG. 2. - Effects of season of birth (spring vs autumn) on ovarian maturity. 
sexually mature than those in the CTRL and SA groups. The distribution was similar in the CTRL and SA groups, even though a few more gilts were pubertal in the control than in the restricted group (CTRL : $32 \% ;$ SA : $20 \% ; P>0.1$ ). Season (replicates $1+3$ vs replicates $2+4$ ) had no significant effect on the percentage of pubertal gilts $(P>0.1$; fig. 2).

Within the CTRL and SA groups, pubertal gilts were significantly older than prepubertal ones but there was no significant difference in their live weights (table 5). Within the SW group, age and live weight were similar in mature and immature gilts.

Pubertal gilts had a higher percentage of fat tissue than immature ones $127.3 \%$ vs $25.9 \% ; P<0.05)$, even though the difference was not significant within each treatment group (table 5).

TABLE 5

Age, live weight and carcass traits in puberal and prepuberal gilts within each treatment group (means \pm SEM).

\begin{tabular}{lcccccc}
\hline Treatment & Stage of maturity & $\mathrm{n}$ & $\begin{array}{c}\text { Age } \\
\text { (days) }\end{array}$ & $\begin{array}{c}\text { Live weight } \\
(\mathrm{kg})\end{array}$ & $\begin{array}{c}\% \text { lean } \\
\text { tissue }\end{array}$ & $\begin{array}{c}\% \text { fat } \\
\text { tissue }\end{array}$ \\
\hline CTRL & Prepuberal gilts & 32 & $193 \pm 2^{\mathrm{b}}$ & $125.2 \pm 0.3$ & $46.3 \pm 0.6$ & $31.9 \pm 0.8$ \\
& Puberal gilts & 15 & $206 \pm 3^{\mathrm{a}}$ & $126.4 \pm 0.6$ & $45.2 \pm 1.0$ & $34.0 \pm 1.1$ \\
\hline SW & Prepuberal gilts & 10 & $266 \pm 10$ & $125.7 \pm 0.5$ & $51.8 \pm 0.7$ & $24.0 \pm 0.7$ \\
& Puberal gilts & 38 & $260 \pm 40$ & $125.1 \pm 0.4$ & $50.3 \pm 0.4$ & $26.1 \pm 0.5$ \\
\hline SA & Prepuberal gilts & 33 & $195 \pm 2^{\mathrm{b}}$ & $91.1 \pm 1.6$ & $54.0 \pm 0.5$ & $20.7 \pm 0.5$ \\
& Puberal gilts & 8 & $207 \pm 3^{\mathrm{a}}$ & $95.2 \pm 4.8$ & $\mathbf{5 5 . 3} \pm 0.5$ & $20.3 \pm 0.7$ \\
& & & & & &
\end{tabular}

Within treatment groups, means with different superscripts differ significantly $(P<0.05)$.

Ovarian development. - Whatever the pubertal status (cyclic or not), the ovaries weighed less in the SA than in the CTRL and SW gilts (table 6), and partial correlations were higher with live weight than with age (table 7).

In the cyclic gilts, corpora lutea weight and number were lower in the SA than in the CTRL and SW gilts, even though the differences were not significant. Partial correlations were higher with live weight than with age.

Regardless of the treatment, ovarian weight increased significantly after puberty, while it did not vary between ovarian classes 1, 2 and 3 (table 8). Ovarian weight and corpora lutea weight and number tended to be higher in gilts with more than one oestrous cycle than in those slaughtered during the first luteal phase.

Development of the cervix and uterine horns. - In prepubertal gilts, uterine horn weight and length as well as cervix weight and length were significantly higher in SW than in SA animals, while CTRL gilts were intermediate (table 6). Partial correlations of cervix traits were significant with both age and live weight, while uterine horn weight was significantly correlated with age only and uterine 
horn length with live weight only (table 7). The weight and length of the cervix and uterine horns tended to increase from class 1 to class 3 ovaries (table 8 ).

Regardless of treatment, the weight and length of the uterine horns increased $(P<0.01)$ markedly after the onset of puberty $(\times 4.0$ and $\times 2.0$, respectively). Cervix weight and length increased $(P<0.01)$ to a lesser extent $(\times 1.4$ and $\times 1.2$, respectively) after puberty.

TABLE 6

Genital tract development in gilts at slaughter (means \pm SEM).

\begin{tabular}{|c|c|c|c|}
\hline Treatment & CTRL & SW & SA \\
\hline $\begin{array}{l}\text { Prepuberal gilts } \\
\text { Ovarian weight }(\mathrm{g}) \ldots \ldots \ldots \ldots \\
\text { Uterine horn weight }(\mathrm{g}) \ldots \ldots \ldots \\
\text { Uterine horn length }(\mathrm{cm}) \ldots \ldots \ldots \\
\text { Cervix weight }(\mathrm{g}) \ldots \ldots \ldots \ldots \ldots \\
\text { Cervix length }(\mathrm{cm}) \ldots \ldots \ldots \ldots \ldots\end{array}$ & $\begin{array}{l}7.0 \pm 0.3^{a} \\
87 \pm 8^{a b} \\
102 \pm 4^{a b} \\
95 \pm 5^{b} \\
21.1 \pm 0.5^{b} \\
32\end{array}$ & $\begin{aligned} & 6.6 \pm 0.6^{\mathrm{ab}} \\
& 117 \pm 12^{\mathrm{a}} \\
& 114 \pm 6^{\mathrm{a}} \\
& 126 \pm 9^{\mathrm{a}} \\
& 24.1 \pm 0.6^{\mathrm{a}} \\
& \frac{10}{12}\end{aligned}$ & $\begin{aligned} & 5.9 \pm 0.2^{\mathrm{b}} \\
& 74 \pm 99^{\mathrm{b}} \\
& 93 \pm 4^{\mathrm{b}} \\
& 67 \pm 0.5^{\mathrm{c}} \\
& 19.2 \pm 0.5^{\mathrm{c}} \\
& \quad 33\end{aligned}$ \\
\hline $\begin{array}{l}\text { Puberal gilts } \\
\text { Ovarian weight }(\mathrm{g}) \ldots \ldots \ldots \ldots \\
\text { Corpora lutea weight }(\mathrm{g}) \ldots \ldots \ldots \\
\text { Corpora lutea number } \ldots \ldots \ldots \\
\text { Uterine horn weight }(\mathrm{g}) \ldots \ldots \ldots \\
\text { Uterine horn length }(\mathrm{cm}) \ldots \ldots \ldots \\
\text { Cervix weight }(\mathrm{g}) \ldots \ldots \ldots \ldots \ldots \\
\text { Cervix length }(\mathrm{cm}) \ldots \ldots \ldots \ldots\end{array}$ & $\begin{aligned} 11.5 & \pm 1.5^{\mathrm{ab}} \\
5.2 & \pm 0.8 \\
14.9 & \pm 1.1 \\
376 & \pm 31^{\mathrm{b}} \\
212 & \pm 25 \\
140 \pm 10 & \pm 10 \\
26.9 \pm 0.6^{\mathrm{a}} & \\
& \pm 14\end{aligned}$ & $\begin{aligned} 12.4 & \pm 0.6^{\mathrm{a}} \\
5.6 & \pm 0.4 \\
14.6 & \pm 0.4 \\
538 & \pm 29^{\mathrm{a}} \\
245 & \pm 10 \\
129 & \pm 6 \\
26.1 \pm 0.6^{\mathrm{ab}} & \\
& 38\end{aligned}$ & $\begin{array}{l}8.1 \pm 1.3^{b} \\
3.6 \pm 0.8 \\
12.5 \pm 0.4 \\
382 \pm 82^{b} \\
188 \pm 17 \\
107 \pm 9 \\
23.5 \pm 0.4^{b} \\
8\end{array}$ \\
\hline
\end{tabular}

In the same line, means with different superscripts differ significantly $(P<0.05)$.

TABLE 7

Coefficients of partial correlation between genital tract development traits and age or live weight.

\begin{tabular}{|c|c|c|}
\hline & \multirow{2}{*}{\multicolumn{2}{|c|}{ Partial correlation with }} \\
\hline & & \\
\hline & Age & Live weight \\
\hline \multicolumn{3}{|l|}{ Prepuberal gilts $(n=75)$} \\
\hline Ovarian weight $(g) \ldots$ & $-0.20+$ & $0.39 * *$ \\
\hline Uterine horn weight $(\mathrm{g})$ & $0.30^{*}$ & 0.16 \\
\hline Uterine horn length $(\mathrm{cm})$ & $0.20+$ & $0.25^{*}$ \\
\hline Cervix weight $(\mathrm{g}) \ldots \ldots$ & $0.29^{*}$ & $0.44^{* *}$ \\
\hline Cervix length $(\mathrm{cm})$ & $0.33^{* *}$ & $0.39 * *$ \\
\hline \multicolumn{3}{|l|}{ Puberal gilts $(n=60)$} \\
\hline Ovarian weight $(\mathrm{g})$ & 0.06 & $0.37^{* *}$ \\
\hline Corpora lutea weight (g) & 0.02 & $0.30^{*}$ \\
\hline Corpora lutea number... & 0.01 & 0.21 \\
\hline Uterine horn weight $(g)$ & $0.42^{* *}$ & 0.15 \\
\hline Uterine horn length (cm) & 0.09 & $0.22+$ \\
\hline Cervix weight $(\mathrm{g})$. & 0.09 & $0.22+$ \\
\hline Cervix length $(\mathrm{cm})$ & 0.04 & 0.04 \\
\hline
\end{tabular}

$+\mathrm{P}<0.1 ;{ }^{*} \mathrm{P}<0.05 ;{ }^{*} \mathrm{P}<0.01$. 
TABLE 8

Effect of ovarian class of maturity on genital tract development of gilts (means were ajusted on the treatment effect).

\begin{tabular}{cccccccc}
\hline & \multicolumn{7}{c}{ Class of ovarian maturity } \\
\cline { 2 - 7 } & 1 & 2 & 3 & 4 & 5 & r.s.d. \\
\hline Ovarian weight $(\mathrm{g}) \ldots \ldots \ldots \ldots \ldots$ & $7.3^{\mathrm{b}}$ & $6.5^{\mathrm{b}}$ & $6.3^{\mathrm{b}}$ & $10.2^{\mathrm{a}}$ & $12.5^{\mathrm{a}}$ & 3.0 \\
Corpora lutea weight $(\mathrm{g}) \ldots \ldots \ldots \ldots$ & - & - & - & 4.6 & 5.9 & 2.7 \\
Corpora lutea number $\ldots \ldots \ldots \ldots$ & $-\bar{c}$ & - & - & 13.9 & 14.9 & 2.9 \\
Uterine horn weight $(\mathrm{g}) \ldots \ldots \ldots \ldots$ & $76^{\mathrm{b}}$ & $96^{\mathrm{b}}$ & $147^{\mathrm{b}}$ & $410^{\mathrm{a}}$ & $510^{\mathrm{a}}$ & 120 \\
Uterine horn length $(\mathrm{cm}) \ldots \ldots \ldots$ & $92^{\mathrm{b}}$ & $110^{\mathrm{b}}$ & $108^{\mathrm{b}}$ & $210^{\mathrm{a}}$ & $239^{\mathrm{a}}$ & 48 \\
Cervix weight $(\mathrm{g}) \ldots \ldots \ldots \ldots \ldots \ldots$ & $78^{\mathrm{c}}$ & $991^{\mathrm{bc}}$ & $113^{\mathrm{abc}}$ & $127^{\mathrm{a}}$ & $117^{\mathrm{ab}}$ & 32 \\
Cervix length $(\mathrm{cm}) \ldots \ldots \ldots \ldots \ldots$ & $20.4^{\mathrm{c}}$ & $21.0^{\mathrm{c}}$ & $22.5^{\mathrm{bc}}$ & $25.5^{\mathrm{ab}}$ & $25.1^{\mathrm{ab}}$ & 2.9 \\
\hline $\mathrm{n}$ & 19 & 40 & 16 & 31 & 29 & \\
\hline
\end{tabular}

In the same line, means with different superscripts differ significantly $(P<0.05)$.

Uterine horn weight was higher $(P<0.01)$ in cyclic gilts of group SW than in those of the SA and CTRL groups and was significantly correlated with age but not with live weight (tables 6, 7). Uterine horn weight tended to increase again after the first oestrous cycle.

\section{Discussion.}

Boar genital tract development. - There was no effect of age on testis weight in boars of similar live weight (around $125 \mathrm{~kg}$ ), although there was a 60-day difference between the two groups. Moreover, partial correlation of testis weight with age was close to zero after the common effect of live weight was eliminated. Therefore, in agreement with Einarsson et al. (1979), age had no influence on testis development at around $125 \mathrm{~kg}$ of live weight. On the other hand, we found a significant age effect on the development of the epididymis, seminal vesicles and bulbourethral glands, while Einarsson et al. (1979) reported no effect. However, the age difference between their ad libitum and restricted boars was much less than in the present study (14 vs 60 days).

In boars around 180 days old, genital tract development was significantly reduced in restricted animals weighing $35 \mathrm{~kg}$ less than the controls. The significant partial correlations with live weight also suggest that body weight influenced boar genital tract development. In boars 235 days old, Uzu (1979) also found a significant live weight effect on testis weight but none on the weight of the epididymis and accessory sex glands. However, growth reduction was due to protein deficiency and resulted in a body weight difference of only $11 \mathrm{~kg}$.

Thus, the effect of live weight prevailed over that of age in testis development, whereas the growth of the epididymis, seminal vesicles and bulbourethral glands was affected by both criteria. Body weight influence on accessory gland development was likely since these glands are the target organs of testicular ste- 
roids (Joshi and Raeside, 1973 ; Morat et al. 1980 ; Booth, 1980, 1983 ; Lauwers et al., 1981) and undernutrition is known to reduce androgen production (Dickerson et al., 1964 ; Bonneau, 1987).

Onset of puberty in gilts. - At around $125 \mathrm{~kg}$ of live weight, age had a significant effect on puberty attainment since the percentage of cyclic gilts was much higher in restricted ones slaughtered about 55 days later than in the control gilts.

Around $\mathbf{2 0 0}$ days of age, the percentage of pubertal gilts was slightly higher in ad libitum than in restricted animals which weighed $33 \mathrm{~kg}$ less. Pubertal gilts of both groups were significantly older than the immature ones, while their live weights were similar.

Thus, age appears to prevail over live weight in puberty attainment in gilts. This is in agreement with the results of Den Hartog and Noordewier (1984) but not with those of Etienne et al. (1983). However, the growth performances in the study of Den Hartog and Noordewier (1984) were similar to ours, while in that of Etienne et al. (1983) gilts fed ad libitum had a slower growth rate so that they were one month older at $125 \mathrm{~kg}$ of live weight.

It has been reported that a minimal fat-to-lean-mass ratio is necessary for puberty attainment and the maintenance of reproductive ability in women and rats (Frisch and MacArthur, 1974 ; Frisch, 1984). In our study, cyclic gilts were fatter than immature ones, but the difference was of a much smaller amplitude than that due to age or live weight, so that pubertal restricted gilts were leaner than prepuberal ones fed ad libitum. Thus, if fatness level influences sexual development in gilts, it has less effect than age. In fact, the relation between backfat thickness and age at puberty is reported to be low in gilts (Cunningham et al., 1974 ; Friend et al., 1981 ; Hutchens et al., 1981 ; Den Hartog and Noordewier, 1984).

Our results show no effect of season of birth (spring vs autumn) on onset of puberty. In fact, the literature on the effect of season on age at puberty is very conflicting (Prunier and Etienne, 1984).

Ovarian development. - Ovarian weight in immature and cyclic gilts as well as corpora lutea weight and number in cyclic gilts were lower in animals of $90 \mathrm{~kg}$ of live weight than in those of $125 \mathrm{~kg}$ of live weight. Some of these differences were not significant due to the small number of pubertal gilts $(n=8)$ slaughtered around $90 \mathrm{~kg}$ of live weight. Ovarian weight was significantly correlated with body weight but not with age in cyclic and immature gilts. Thus, live weight per se seems to influence ovarian development. A similar increase of ovarian weight with live weight has been described by Friend (1976) in cyclic gilts. Moreover, it has often been reported that live weight effect prevails over that of age in gilt ovulation rate (Etienne and Duée, 1973; Young et al., 1974; Duée et al., 1980 ; Etienne et al., 1983). The effect of live weight on follicular development has been poorly studied in gilts. Dufour et al. (1985) did not find any effect of plane of nutrition on the total number of atretic and non-atretic follicles in gilts of various ages during the prepubertal period. 
Development of the cervix and uterine horns. - The weight and length of the cervix and uterine horns were similar to those reported by Etienne and Legault (1974) in prepubertal and cyclic Landrace and Pietrain gilts.

In immature gilts, weight and length of the cervix and uterine horns increased with the ovarian class of maturity. Since the genital tract is a target organ of oestrogen, its development may reflect an enhancement of oestrogen production from class 1 to class 3 ovaries. Regardless of ovarian maturity, genital tract development increased with age and live weight. Partial correlation of uterine horn weight was higher with age than live weight, while opposite results were obtained for uterine horn length and cervix length and weight. Thus, the genital tract development of immature gilts is influenced by both age and live weight. However, uterine horn weight is more dependent on age, whereas uterine length and cervix weight and length are more affected by live weight.

The onset of puberty induced a marked increase in uterine horn weight and length and a slight increase of cervix traits. The uterine horns of cyclic gilts were heavier at 260 than at $\mathbf{2 0 0}$ days. This difference was not due to the number of previous oestrous cycles since it was still present in the subgroup of gilts slaughtered during the first cycle. In cyclic gilts, uterine horn weight was significantly correlated with age but not with live weight. Therefore, the uterine horn weight of mature gilts was mainly influenced by age. The effects of age or live weight on uterine horn length and cervix traits are not obvious.

\section{Conclusion.}

The effect of age prevails over that of live weight as concerns the onset of puberty in gilts. However, a possible effect of live weight cannot be excluded. The influence of food restriction may depend on the growth performance of animals fed ad libitum since age may limit puberty attainment in gilts with a high growth rate. Retarded growth may also have specific effects during limited periods of sexual development, and this point needs further investigation.

Live weight per se influences gonad weight in boars and gilts. Both age and live weight affect the development of the accessory sex glands in boars and that of the uterus in prepubertal gilts. These effects might be mediated by changes in steroid production and/or metabolism due to age and live weight.

Reçu en décembre 1986. Accepté en février 1987.

Acknowledgements. - The authors gratefully acknowledge the technical assistance of G. Conseil, F. Giovanni, A. M. Mounier, Y. Peignier and C. Vachot.

Résumé. Influences respectives de l'âge et du poids sur le développement sexuel de jeunes porcs mâles et femelles nourris selon deux plans d'alimentation.

Le but de cette expérience est de déterminer les influences respectives de l'âge et du poids vif sur le développement sexuel de jeunes porcs mâles et femelles. Les animaux (141 
mâles, 136 femelles) de race Large White sont nourris selon un plan d'alimentation libéral proche du niveau ad libitum (groupe CTRL) ou restreint de près de $30 \%$ sur la base du poids vif (groupe SA et SW). Les animaux CTRL et SW sont abattus vers $125 \mathrm{~kg}$ de poids vif et ceux du groupe SA au même âge que leur frère ou sœur de portée du groupe CTRL. Les porcs SA pèsent alors environ $90 \mathrm{~kg}$ de poids vif. Les animaux CTRL et SA sont âgés de 180 (mâles) ou 200 jours (femelles) et ceux du groupe SW de 240 (mâles) ou 260 jours (femelles). Les tractus génitaux sont collectés et examinés à l'abattage.

Le poids des testicules augmente significativement avec le poids vif mais ne varie pas avec l'âge tandis que celui des épididymes, des vésicules séminales et des glandes bulbouréthrales ainsi que la longueur de ces dernières s'élèvent à la fois avec le poids vif et l'âge.

Chez les femelles, l'âge a une influence significative sur l'apparition de la puberté tandis que le poids a peu d'effet. Le pourcentage de femelles cycliques dans les groupes CTRL, SW et SA est respectivement de 32,79 et 20 . Le poids des ovaires dépend beaucoup plus du poids vif que de l'âge chez les femelles cycliques et chez les immatures. Chez ces dernières le poids et la longueur des cornes utérines et du col de l'utérus augmentent avec l'âge et le poids vif tandis que chez les femelles cycliques seul le poids des cornes utérines varie avec l'âge indépendamment du nombre de cycles précédents. La saison de naissance (automne vs printemps) est sans effet sur le pourcentage de femelles cycliques.

\section{References}

BONNEAU M., 1987. The effect of age and live weight on fat $5 \alpha$ androstenone levels in young boars fed two planes of nutrition. Reprod. Nutr. Dévelop., 27. 413-422.

BOOTH W. D., 1980. A study of some major testicular steroids in the pig in relation to their effect on the development of male characteristics in the prepubertally castrated boar. J. Reprod. Fert., 59, 155-162.

BOOTH W. D., 1983. Development of some male characteristics supported by oestrone but not dehydroepiandrosterone in the boar. J. Reprod. Fert., 68, 9-16.

CUNNINGHAM P. J., NABER C. H., ZIMMERMAN D. R., PEO J., 1974. Influence of nutritional regime on age at puberty in gilts. J. anim. Sci., 39, 63-67.

DEN HARTOG L. A., NOORDEWIER G. J., 1984. The effect of energy intake on age at puberty in gilts. J. agric. Sci., 32, 263-280.

DESMOULIN B., GRANDSARD P., TASSENCOURT L., 1976. Les critères d'appréciation de la composition anatomique de la carcasse de porc et des pièces de découpe. Principes généraux et difficultés de classification. Journées Rech. Porcine en France, 8, 89-98.

DICKERSON J. W. T., GRESHAM G. A., Mac CANCE R. A., 1964. The effect of undernutrition and rehabilitation on the development of reproductive organs in pigs. J. Endocrinol., 29, 111-118.

DUTT R. H., BARNHART C. E., 1959 . Effect of plane of nutrition upon reproductive performance of bóars. J. anim. Sci, 18, 3-13.

DUÉE P. H., TREIL F., CAMOUS S., 1980. Influence de l'apport protéique durant la croissance et la première gestation sur les performances de reproduction et la composition corporelle chez la truie. Ann. Zootech., 29, 121-136.

DUFOUR J. J., FAHMY M. H., FLIPOT P. M., 1985. Follicular development during the prepubertal period of different morphological types of ovaries in Hampshire and Yorkshire gilts fed two planes of nutrition. J. anim. Sci., 6?, 1201-1210.

EINARSSON S., HOLTMAN M., LARSSON K., SETTERGREN I., BANE A., 1979. The effect of two feed levels on the development of reproductive organs in boars. Acta vet. scand., 20. $1-9$.

ETIENNE M., DUÉE P. H., 1973. Effects respectifs des niveaux alimentaires pendant la croissance et le premier mois de gestation sur les performances de reproduction chez la truie nullipare : résultats préliminaires. Ann. Zootech., 22, 453-462.

ETIENNE M., LEGAULT C., 1974. Influence de la race et du régime alimentaire sur la précocité sexuelle de la truie. Journées Rech. Porcine en France, 6, 57-62. 
ETIENNE M., CAMOUS S., CUVILLIER A., 1983. Effets de restrictions alimentaires pendant la croissance des truies sur leur maturité sexuelle et leur reproduction ultérieure. Reprod. Nutr. Dévelop., 23, 309-319.

FRIEND D. W., 1973. Influence of dietary amino acids on the age at puberty of Yorkshire gilts. J. anim. Sci., 37, 701-707.

FRIEND D. W., 1976. Nutritional effects on age at puberty and plasma amino acid level in Yorkshire gilts and on chemical composition, nucleic acid, fatty acid and hydroxyproline contents of the uterus. J. anim. Sci., 43, 404-412.

FRIEND D. W., 1977. Effect of dietary energy and protein on age at puberty of gilts. J. anim. Sci., 44, 601-607.

FRIEND D. W., LODGE G. A., ELLIOT J. I., 1981. Effect of energy and dry matter intake on age, body weight and backfat at puberty and on embryo mortality in gilts. J. anim. Sci., 53, 118-124.

FRISCH R. E., MacARTHUR J. W., 1974. Menstrual cycles : Fatness as determinant of minimum weight for height necessary for their maintenance or onset. Sciences, 185, 149-151.

FRISCH R. E., 1984. Body fat, puberty and fertility. Biol. Rev., 59, 161-188.

HUGHES P. E., COLE D. J. A., 1975. Reproduction in the gilt 1 . Influence of age and weight at puberty on ovulation rate and embryo survival. Anim. Prod., 21, 183-189.

HUTCHERS L. K., HINTZ R. L., JOHNSON R. K., 1981. Genetic and phenotypic relationships between puberal and growth characteristics of gilts. J. anim. Sci., 53, 946-951.

JOSHI H. S., RAESIDE J. I., 1973. Synergistic effects of testosterone and oestrogens on accessory sex glands and sexual behaviour of the boar. J. Reprod. Fert., 33, 411-423.

KIM J. K., SUH G. S., SUL D. S., KIM U. B., LEE Y., 1976. Studies on sexual maturity and the optimum age for breeding in the boar. 1 - Spermatogenic function and the effects of nutritional level on sexual maturity. Res. Rep. Off. Rural Dev., Livest. Ser., 18, 29-42.

KIRKWOOD R. N., AHERNE F. X., 1985. Energy intake, body composition and reproductive performance of the maiden gilt. J. anim. Sci., 60, 1518-1529.

LAUWERS H., GYSELBRECHT C., SIMOENS L., NICAISE M., de VOS N. R., 1981. Morphological detection of hormone treatment in barrows. Archiv. Lebensmittelhyg., 32, 77-82.

LODGE G. A., MacPHERSON R. M., 1961. Level of feeding during early life and the subsequent reproductive performance of sows. Anim. Prod., 3, 19-28.

LODGE G. A., MacPHERSON R. M., 1963. The influence of plane of feeding in early life on the fertility of gilts. Anim. Prod., 5, 43-46.

MAVROGENIS A. P., ROBISON O. W., 1976. Factors affecting puberty in swine. J. anim. Sci., 42, 1251-1255.

MORAT M., LOCATELl A., TERQUI M., ChEVALIER M., ChAMBON M., DUfAURE J. P., 1980. Effets de l'hypophysectomie puis de l'administration de la gonadotropine HCG sur le taux de testostérone plasmatique et sur la structure de l'épididyme et des glandes accessoires chez le verrat (Sus scrofa L.). Reprod. Nutr. Dévelop., 20, 61-76.

NIWA T., 1954. Studies on spermatogenic function in swine. Relationship between body growth and spermatogenic function. Bull. nat. Inst. agric. Sci. Japan, 8, 17-29.

PAY M. G., DAVIES T. E., 1973. Growth, food consumption and litter production of female pigs mated at puberty and at low body weights. Anim. Prod., 17, 85-91.

PRUNIER A., ETIENNE M., 1984. Effects of confinement on attainment of puberty in gilts. Ann. Rech. vet., 15, 159-164.

ROBERSTON G. L., GRUMMER R. H., CASIDA L. E., CHAPMAN A. B., 1951. Age at puberty and related phenomena in outbred Chester White and Poland China gilts. $J$. anim. Sci., 10. 647-656.

UZU G., 1979. Influence de l'alimentation azotée entre 30 et $90 \mathrm{~kg}$ de poids vif sur les performances de reproduction du jeune verrat. Ann. Zootech., 28, 431-441.

YOUNG L. D., OMTVEDT I. T., JOHNSON R. K., 1974. Relationship of various measures of performance with ovulation rate and number of embryos 30 days after breeding in gilts. J. anim. Sci., 39, 480-487. 